\title{
Reaction of Allyl Radical with Acetylene
}

\author{
Daisuke Nohara* and Tomoya SAKaI*
}

\begin{abstract}
The title reaction was performed at $580 \sim 740^{\circ} \mathrm{C}$, employing biallyl as the source of the allyl radical. The main product of addition of allyl radical to acetylene was cyclopentadiene, and the selectivity attained was more than 90 percent of the total $\mathrm{C}_{5}$ products. Such acyclic product as 1,4-pentadiene was scarcely formed in distinct contrast with the result of the addition of allyl radical to ethylene, in which almost equal amounts of 1-pentene and cyclopentene were formed. The product distribution of the title reaction was reported, and a scheme for the product formation was proposed. From the kinetic analysis, the overall activation energy of reaction for the formation of cyclopentadiene from allyl radical and acetylene was estimated.
\end{abstract}

\section{Introduction}

Allyl radical has been suggested as playing the role of diene ${ }^{1)}$ in the cyclization reaction with olefins to form $\mathrm{C}_{5}$-cyclic products analogous to butadiene which thermally combines with olefins to yield $\mathrm{C}_{6}$-cyclic compounds. In the pyrolysis of ethylene ${ }^{2)}, \mathrm{C}_{6}$-cyclic compounds were formed mostly through the Diels-Alder reaction between butadiene and ethylene, the butadiene being one of the primary products of the reaction.

$$
\leqslant+\| \longrightarrow \stackrel{-2 \mathrm{H}_{2}}{\longrightarrow} \square
$$

On the other hand, greater amounts of $\mathrm{C}_{5}$-cyclic compounds were produced in the pyrolysis of propylene $^{3)}$ than in the case of ethylene. It was suggested that, in the case of propylene, the difference originated from the contribution of the allyl radical that was formed through the following reaction:

$$
\ll+\pi \longrightarrow \square, \widehat{Q}+\mathrm{H} \cdot
$$

In our study on the pyrolysis of 1,5-hexadiene (biallyl) ${ }^{4}, \mathrm{C}_{5}$-cyclic compounds such as cyclopentadiene and cyclopentene were produced as the primary products. It is considered that these compounds were formed by the addition of allyl radical to biallyl. Furthermore, in the pyrolysis of biallyl in excess ethylene ${ }^{5}$, cyclopentene and 1-pentene were formed with fairly good selectivities, i.e., the total amount of the two products was ca. $60 \%$ of all products produced.

Received June 18, 1979.

* Dept. of Chemical Reaction Engineering, Faculty of Pharmaceutical Sciences, Nagoya City University (3-1, Tanabedori, Mizuho-ku, Nagoya 467)
The present experiment on thermal reaction of biallyl with acetylene was undertaken to examine the possibility of cycloaddition of allyl radical to the triple bond. Cyclopentadiene, one of the expected $\mathrm{C}_{5}$ compounds in the present reaction, was formed in high selectivity, i.e., ca. 40 percent of all products, including the products from the thermal reaction of acetylene itself. The selectivity was formed to be as high as 60 percent, excluding the products from the reaction of acetylene itself. A characteristic feature of the reaction of allyl radical with the triple bond was that an acyclic $\mathrm{C}_{5}$ compound such as 1,4-pentadiene was scarcely formed. This result was quite different from the result obtained in the thermal reaction of biallyl in excess ethylene ${ }^{5}$, where the amount of 1-pentene was as abundant as that of cyclopentene.

\section{Experimental}

The apparatus used was an ordinary atmospheric flow system. The reactor was made of a quartz annular cylinder. Reactants and products were analyzed mostly with a FID gas chromatograph equipped with a di- $n$-butylmaleate capillary column. Identification of products was confirmed by GGMS. Reaction temperatures were in the range from $580^{\circ} \mathrm{C}$ to $740^{\circ} \mathrm{C}$, and residence times were 0.09 to $0.3 \mathrm{sec}$. Equivalent reactor volumes at the temperatures employed were calculated by the method of Hougen and Watson ${ }^{6}$. Acetylene, freed from acetone vapor, was diluted with deoxygenated nitrogen to around $4 \mathrm{vol} \%$. Biallyl vapor was mixed with the acetylene- $\mathrm{N}_{2}$ flow and fed into the reactor. Biallyl concentrations were adjusted around $0.16 \mathrm{vol} \%$ of the inlet gas. The thermal reaction of acetylene without biallyl vapor was conducted as a blank test. 


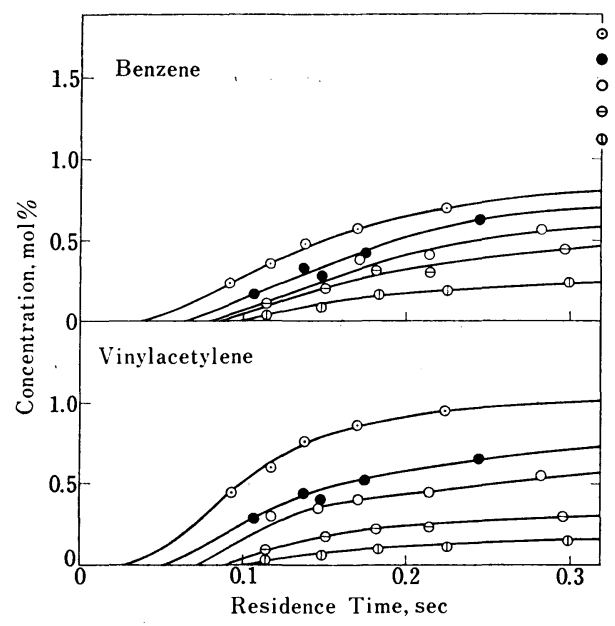

(a)

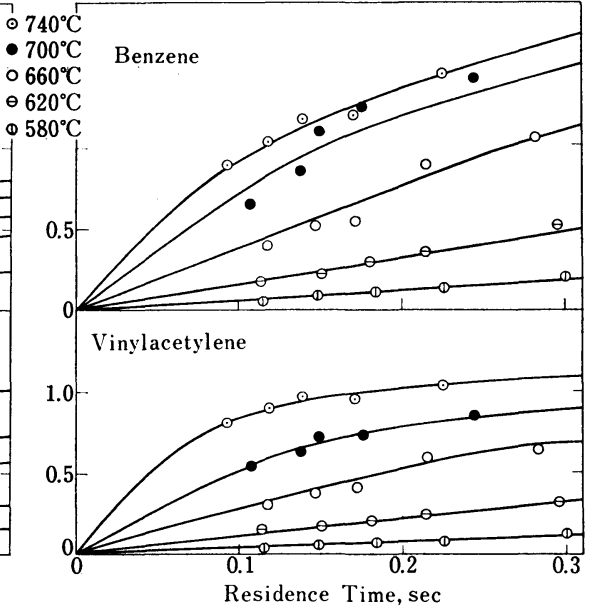

(b)

Fig. 1 Product Formation Curve in the Thermal Reaction of Acetylene

\section{Results and Discussion}

As blank reference for the title reaction, the results and discussion on the thermal reaction of acetylene- $\mathrm{N}_{2}$ will first be briefly described. It will then be followed by a description of the results and discussion of the title reaction of allyl radical with acetylene.

\subsection{Thermal Reaction of Acetylene}

The products obtained in the thermal reaction of acetylene under the present conditions used, i.e., ca. $4 \mathrm{vol} \%$ acetylene in $\mathrm{N}_{2}$ at $580 \sim 740^{\circ} \mathrm{C}$ for $0.09 \sim 0.3 \mathrm{sec}$, were vinylacetylene, benzene and 1,3,5-hexatriene. The presence of the last compound was indicated from the retention time of glc, but the amount was too small to be identified by GC-MS.

The temperatures used in the present experiments were in the lower temperature range classified by Back $^{7}$ ) in his study on acetylene pyrolysis where the formation of vinylacetylene and benzene was claimed as the main products),8). In the lower part of the present temperature range used, polymerization seemed to become predominant ${ }^{7}$. Relations between product concentrations and residence times are illustrated in Fig. 1 (a). The presence of an induction period was evident as in other reports ${ }^{9), 10)}$. The time courses of concentrations of vinylacetylene and benzene with the addition of biallyl vapor are shown in Fig. 1 (b). The induction period was shortened as observed by many investigators who had pointed out the same trend ${ }^{11), 12)}$ when another appropriate radical source existed. The temperature dependency of the rate of formation of vinylacetylene or benzene expressed in terms of apparent activation energy was 110 or $54 \mathrm{~kJ} \mathrm{~mol}^{-1}$ without the addition of biallyl; with the addition of biallyl, however, it changed to 150 or $130 \mathrm{~kJ} \mathrm{~mol}^{-1}$, respectively. These facts reflect the complexity in the latter case, i.e., the intermediate radicals in one chain reaction system affect the reactions of the other system. Common intermediate radicals such as ethynyl and vinyl are expected to be involved in the chains of both systems.

\subsection{Reaction of Allyl Radical with Acetylene}

Fig. 2 shows the Arrhenius plots for the biallyl decomposition in the thermal reaction of acetylenebiallyl- $\mathrm{N}_{2}$ gas mixtures that fitted to a first-order rate equation similar to the ethylene case reported previously5). The runs conducted at $740^{\circ} \mathrm{C}(1 / \mathrm{T}=$ $\left.0.99 \times 10^{-3} \mathrm{~K}^{-1}\right)$ were excluded from the figure since

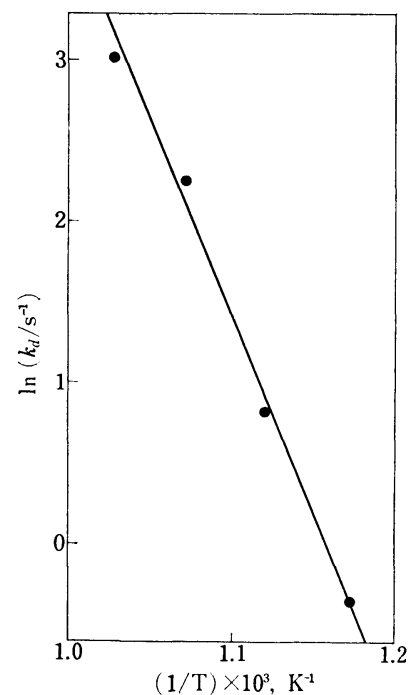

Fig. 2 Arrhenius Plot for the Biallyl Decomposition 
Table 1 Typical Experimental Data

\begin{tabular}{|c|c|c|c|c|c|c|c|c|c|c|}
\hline \multirow{5}{*}{$\begin{array}{l}\text { Temperature, }{ }^{\circ} \mathbf{C} \\
\text { Residence Time, sec } \\
\text { Acetylene Conc., vol } \% \\
\text { Biallyl Conc., vol\% } \\
\text { Obtained Compounds, mol\% }\end{array}$} & \multicolumn{2}{|c|}{580} & \multicolumn{2}{|c|}{620} & \multicolumn{2}{|c|}{660} & \multicolumn{2}{|c|}{700} & \multicolumn{2}{|c|}{740} \\
\hline & 0.115 & 0.226 & 0.114 & 0.215 & 0.118 & 0.215 & 0.107 & 0.176 & 0.093 & 0.118 \\
\hline & 3.85 & 3.95 & 3.66 & 3.72 & 4.50 & 4.02 & 3.30 & 3.33 & 3.72 & 3.28 \\
\hline & 0.126 & 0.157 & 0.126 & 0.140 & 0.160 & 0.125 & 0.123 & 0.137 & 0.131 & 0.132 \\
\hline & 0.027 & 0.054 & 0.108 & 0.233 & 0.324 & 5.512 & 0.631 & 0.959 & 0.850 & 1.058 \\
\hline Acetylene & 96.79 & 96.02 & 96.25 & 95.52 & 95.19 & 95.06 & 93.99 & 92.40 & 93.64 & 92.26 \\
\hline Propylene & & & 0.061 & 0.228 & 0.385 & 0.620 & 0.590 & 0.874 & 0.341 & 0.605 \\
\hline 1-Butene & 0.005 & 0.008 & 0.032 & 0.080 & 0.137 & 0.228 & 0.318 & 0.456 & 0.387 & 0.476 \\
\hline Butadiene & 0.016 & 0.037 & 0.061 & 0.124 & 0.168 & 0.219 & 0.303 & 0.396 & 0.364 & 0.457 \\
\hline 1, 4-Pentadiene & - & - & 0.007 & 0.012 & 0.017 & 0.016 & 0.021 & 0.017 & 0.010 & 0.190 \\
\hline Vinylacetylene & 0.040 & 0.068 & 0.144 & 0.226 & 0.294 & 0.585 & 0.541 & 0.732 & 0.813 & 0.886 \\
\hline 1-Pentene-4-yne & & & 0.014 & 0.034 & - & - & 0.127 & 0.130 & 0.135 & 0.153 \\
\hline Cyclopentadiene & 0.132 & 0.264 & 0.455 & 0.880 & 1.104 & 1.459 & 2.039 & 2.648 & 2.499 & 2.937 \\
\hline Biallyl & 2.932 & 3.426 & 2.607 & 2.228 & 1.898 & 0.301 & 0.638 & 0.066 & 0 & 0 \\
\hline $1,3,5$-Hexatriene & & - & - & 0.036 & 0.028 & 0.039 & 0.050 & 0.052 & 0.042 & 0.053 \\
\hline Benzene & 0.036 & 0.126 & 0.180 & 0.347 & 0.394 & 0.890 & 0.652 & 1.149 & 0.884 & 1.043 \\
\hline
\end{tabular}

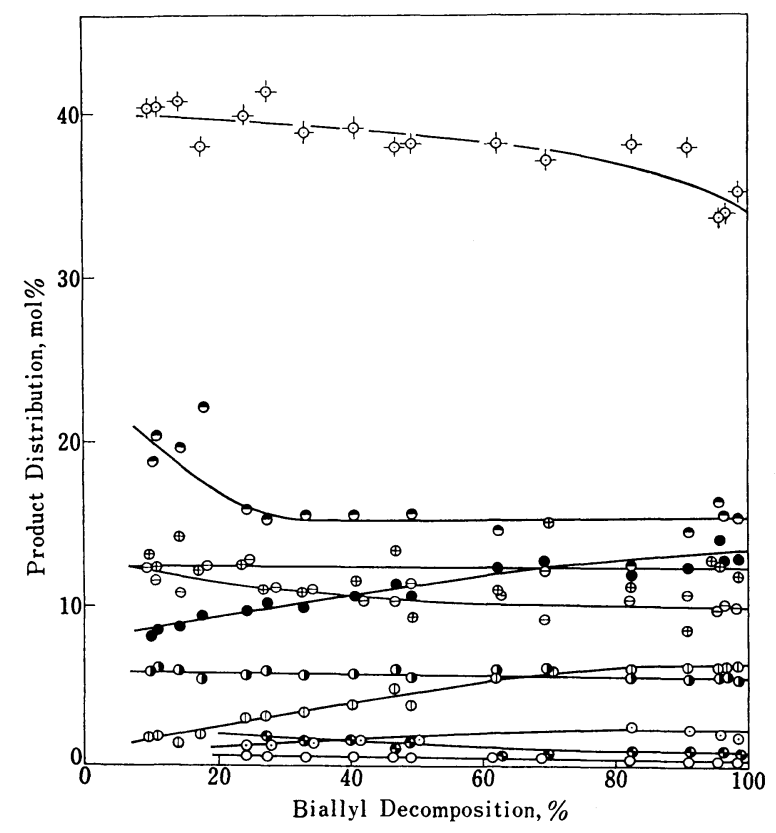

$-\dot{\phi}:$ : Cyclopentadiene, $\oplus:$ Propylene, $\bullet:$ Ethylene,

- :Butadiene, $\odot:$ Butene, $\odot: 1-$ Pentene-4-yne,

$0: 1,4$-Pentadiene, $0:$ Benzene, $\Theta:$ Vinylacetylene,

-:1,3,5-Hexatriene

Fig. 3 Product Distribution in the Reaction of Allyl Radical and Acetylene

biallyl was completely decomposed at that temperature. From this figure, $k_{\mathrm{d}}=10^{12.5} \exp (-209,000 /$ $\mathrm{RT}) \mathrm{s}^{-1}$ was obtained. The kinetic parameters were in numerical agreement with those observed in the ethylene-biallyl case ${ }^{5)}$, indicating that decomposition of biallyl was unaffected by the presence of either ethylene or acetylene.

The main products in the reaction of allyl radical with acetylene were cyclopentadiene, propylene, ethylene, butadiene and 1-butene, in addition to vinylacetylene and benzene; and the minor products were 1,4-pentadiene, 1-pentene-4-yne, 1,3,5hexatriene and methane. Very small amounts of unidentified products were also detected in the $\mathrm{C}_{5}$ to $\mathrm{C}_{6}$ fractions. Typical experimental data are

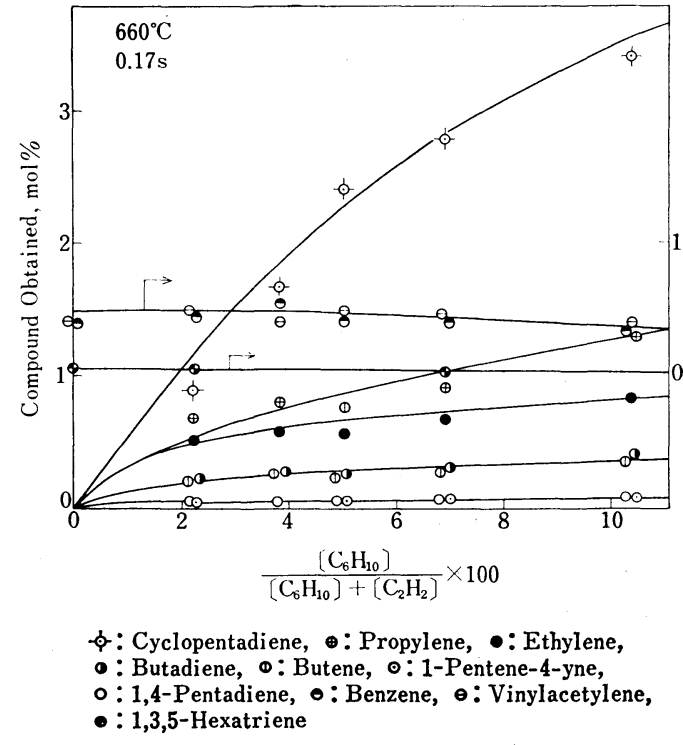

Fig. 4 Effect of Biallyl Concentration on Molar Amounts of Products

listed in Table 1.

The product distribution of this reaction is shown in Fig. 3. It is clear that the amount of cyclopentadiene was ca. $40 \%$ of all products, while that of 1,4-pentadiene was less than $3 \%$. In the products, excluding vinylacetylene and benzene, about $60 \%$ of all products was cyclopentadiene. The present result contrasted sharply with that observed in the ethylene-biallyl system in which 1-pentene was formed in the amount nearly equal to that of cyclopentene ${ }^{5)}$. The striking difference indicates that the cyclization of $\mathrm{C}=\mathrm{C}-\mathrm{C}-\mathrm{C}=\mathrm{C}$ - radical followed by hydrogen atom elimination to produce $\square$ is much faster than hydrogen abstraction by the same radical to produce acyclic product, presumably, because of the absence of available H-donors.

Illustrated in Fig. 4 is the effect of biallyl concentration on the product distribution observed at 
$660^{\circ} \mathrm{C}$ and $0.17 \mathrm{~s}$. The relative amounts of products, excluding vinylacetylene, benzene and 1,3,5hexatriene, which were formed from the thermal reaction of acetylene, increased distinctly with biallyl concentration, indicating clearly that cyclopentadiene was formed through the addition of allyl radical to acetylene.

\subsubsection{Scheme for Product Formations}

The following scheme is proposed for the reactions of acetylene-biallyl- $\mathrm{N}_{2}$ gas mixtures. Biallyl initially decomposes to produce two allyl radicals in Reaction (1).

$$
\mathrm{C}=\mathrm{C}-\mathrm{C}-\mathrm{C}-\mathrm{C}=\mathrm{C} \longrightarrow 2 \mathrm{C}=\mathrm{C}-\mathrm{C} \text {. }
$$

The fate of the allyl radical thus produced will be its addition to acetylene and to biallyl in Reactions (2) and (3) or the abstraction of hydrogen to produce propylene in Reactions (4) and (5).

$$
\begin{aligned}
& \mathrm{C}=\mathrm{C}-\mathrm{C} \cdot+\mathrm{C} \equiv \mathrm{C} \longrightarrow \mathrm{C}=\mathrm{C}-\mathrm{C}-\mathrm{C}=\mathrm{C} . \\
& \mathrm{C}=\mathrm{C}-\mathrm{C} \cdot+\mathrm{C}=\mathrm{C}-\mathrm{C}-\mathrm{C}-\mathrm{C}=\mathrm{C} \longrightarrow \\
& \mathrm{G}=\mathrm{C}-\mathrm{C}-\mathrm{C}-\dot{\mathrm{C}}-\mathrm{C}-\mathrm{C}-\mathrm{C}=\mathrm{C} \\
& \mathrm{C}=\mathrm{C}-\mathrm{C} \cdot+\mathrm{C} \equiv \mathrm{C} \longrightarrow \mathrm{C}=\mathrm{C}-\mathrm{C}+\mathrm{C} \equiv \mathrm{C} . \\
& \mathrm{C}=\mathrm{C}-\mathrm{C} \cdot+\mathrm{C}=\mathrm{C}-\mathrm{C}-\mathrm{C}-\mathrm{C}=\mathrm{C} \longrightarrow \\
& \mathrm{C}=\mathrm{C}-\mathrm{C}+\mathrm{C}=\mathrm{C}-\dot{\mathrm{C}}-\mathrm{C}-\mathrm{C}=\mathrm{C}
\end{aligned}
$$

The ethynyl radical formed in Reaction (4) probably enters into a complicated reaction cycle of acetylene or undergoes polymerization. The radicals formed in Reactions (3) and (5) also undergo complicated polymerizations.

Attention is first focused on the 1,4-pentadienyl-1 radical formed in Reaction (2). The fate of this radical will be cyclization and hydrogen abstraction. The loss of hydrogen from the 1,4-pentadienyl-1 radical can also be considered, but it is not included in our discussion because 1-pentene4-yne was scarcely formed in our experiments. Other possible reactions of this radical are the addition to either acetylene or biallyl similar to Reactions (2) and (3).

$$
\mathrm{C}=\mathrm{C}-\mathrm{C}-\mathrm{C}=\mathrm{C} \cdot \longrightarrow \cdot \square
$$

$\mathrm{C}=\mathrm{C}-\mathrm{C}-\mathrm{C}=\mathrm{C} \cdot+\mathrm{C} \equiv \mathrm{C} \longrightarrow \mathrm{G}=\mathrm{C}-\mathrm{C}-\mathrm{C}=\mathrm{C}+\mathrm{C} \equiv \mathrm{C} \cdot$

$$
\begin{array}{r}
\mathrm{C}=\mathrm{C}-\mathrm{G}-\mathrm{C}=\mathrm{C} \cdot+\mathbf{C}=\mathrm{C}-\mathrm{C}-\mathrm{C}-\mathrm{C}=\mathrm{C} \longrightarrow \\
\quad \mathrm{C}=\mathrm{C}-\mathrm{C}-\mathrm{C}=\mathrm{C}+\mathrm{C}=\mathrm{C}-\dot{\mathrm{C}}-\mathrm{C}-\mathrm{C}=\mathrm{C}
\end{array}
$$

More than $90 \%$ of the total $\mathrm{C}_{5}$ products was cyclopentadiene, while 1,4-pentadiene amounted only to less than $7 \%$. Reaction (6) is therefore considerably faster than the combined total of Reactions (7) and (8).

The cyclopentenyl radical formed in Reaction (6) either releases or abstracts hydrogen. Most of this radical eliminates hydrogen to produce cyclopentadiene according to Reaction (9).

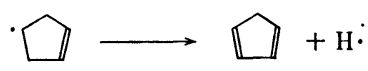

The hydrogen abstraction product, cyclopentene, was not detected in the products. According to the above, only small amounts of hydrogen-donating compounds, other than propylene, are formed.

This behavior is the characteristic feature of a system involving acetylene. The $\mathrm{H}$. released in Reaction (9) adds to acetylene or other compounds, thereby enhancing polymerization and the formation of $\mathrm{C}_{2} \sim \mathrm{C}_{4}$ unsaturated compounds.

As for the formation of ethylene, butadiene and 1-butene, it was observed that the relationship, ethylene $=$ butadiene +1 -butene, was valid for almost the whole region covered by the present experiments, as it was the case of the thermal reaction of biallyl ${ }^{4)}$. This fact implies that, although biallyl decomposes mostly according to Reaction (1), the following type of scission of biallyl partly takes place:

$$
\mathrm{C}=\mathrm{C}-\mathrm{C}-\mathrm{C}-\mathrm{C}=\mathrm{C} \longrightarrow \mathrm{G}=\mathrm{C} \cdot+\mathrm{C}=\mathrm{C}-\mathrm{C}-\mathrm{C} \text {. }
$$

From the butenyl or the vinyl radical, 1-butene and butadiene or ethylene is formed in Reactions (11), (12) or (13).

$$
\begin{aligned}
& \mathrm{C}=\mathrm{C}-\mathrm{C}-\mathrm{C} \cdot+\mathrm{RH} \longrightarrow \mathrm{C}=\mathrm{C}-\mathrm{C}-\mathrm{C}+\mathrm{R} . \\
& \mathrm{C}=\mathrm{C}-\mathrm{C}-\mathrm{C} \cdot \longrightarrow \mathrm{C}=\mathrm{C}-\mathrm{C}=\mathrm{C}+\mathrm{H} . \\
& \mathrm{C}=\mathrm{C} \cdot+\mathrm{RH} \longrightarrow \mathrm{C}=\mathrm{C}+\mathrm{R} .
\end{aligned}
$$

$\mathrm{RH}$ in these Reactions is considered to be acetylene and/or biallyl. As temperature becomes higher, the formation of 1-butene by hydrogen abstraction becomes more important. Provided that ethylene, butadiene and 1-butene are formed through Reactions (10) to (13), and provided that allyl radical is converted exclusively to propylene and cyclopentadiene, the ratio of biallyl decomposition by Reaction (10) to that by (1) will be between 0.15 and 0.25 .

\subsubsection{Kinetic Studies}

The temperature dependency (TD) of the rate for the cyclopentadiene formation was measured to be $113 \mathrm{~kJ} \mathrm{~mol}^{-1}$ in Fig. 5. The TD of the rate for the cyclopentene or 1-pentene formation was measured to be 51.3 or $72.1 \mathrm{~kJ} \mathrm{~mol}^{-1}$ by plotting the data ${ }^{5}$ obtained in a previous ethylenebiallyl system as shown in Fig. 6. The TD was much larger for the cyclopentadiene formation than that for the cyclopentene formation. The rate of the cyclopentadiene formation at $700^{\circ} \mathrm{C}$, however, was 200 times larger than that of the cyclopentene 


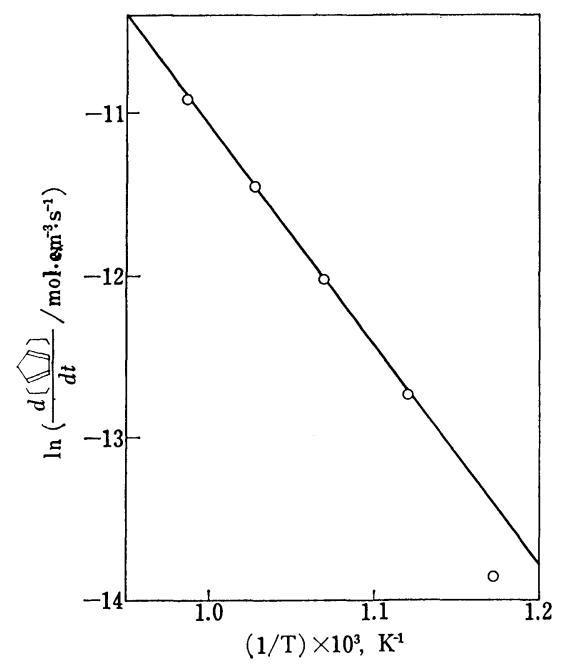

Fig. 5 Temperature Dependency of the Rate of Cyclopentadiene Formation

formation, when a comparison was tentatively made at the same concentration levels of acetylene or ethylene and biallyl. A large pre-exponential factor of the acetylene-biallyl reaction is the cause for this result.

In a previous kinetic analysis made on the diallyloxalate pyrolysis in excess ethylene ${ }^{13}$ ), TD's of $k$-values for cyclopentene and 1-pentene formations were obtained as 48.0 or $69.6 \mathrm{~kJ} \mathrm{~mol}^{-1}$, instead of 51.3 or $72.1 \mathrm{~kJ} \mathrm{~mol}^{-1}$ which is the TD for the rate of cyclopentene or 1-pentene formation in the ethylene-biallyl case. Accordingly, the TD of the concentration of allyl radical within the range from 580 to $700^{\circ} \mathrm{C}$ is apparently obtained as $51.3-$ $48.0=3.3 \mathrm{~kJ} \mathrm{~mol}^{-1}$ from the cyclopentene formation or $72.1-69.6=2.5 \mathrm{~kJ} \mathrm{~mol}^{-1}$ from the 1-pertene formation. As the same temperature region was applied to the present reaction, the TD of the $k$-value for the acetylene-biallyl case could be estimated as $113-(3.3+2.5) / 2=110 \mathrm{~kJ} \mathrm{~mol}^{-1}$. However, the estimation of the $A$-factor for the $k$-value, inspite of its importance in the acetylene-biallyl

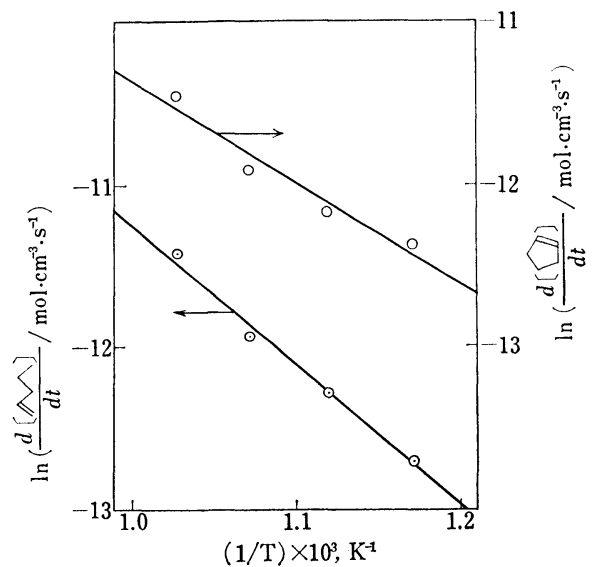

Fig. 6 Temperature Dependency of Cyclopentene or 1-Pentene Formation

reaction, could not be deduced from the kinetic analysis of the present data.

\section{References}

1) Bryce, W. A., Ruzicka, D.J., Can. J. Chem., 38, 835 (1960).

2) Kunugi, T., Sakai, T., Soma, K., Sasaki, Y., Ind . Eng. Chem., Fundamentals, 8, 374 (1969).

3) Kunugi, T., Sakai, T., Soma, K., Sasaki, Y., Ind. Eng. Chem., Fundamentals, 9, 314 (1970).

4) Nohara, D., Sakai, T., Ind. Eng. Chem., Prod. Res. Develop., 12, 322 (1973).

5) Sakai, T., Nohara, D., Bull. Japan Petrol. Inst., 17, (2) 212 (1975) .

6) Hougen, D. A., Watson, K. M., "Chemical Process Principles”, 884 (1943), Wiley, New York, N. Y.

7) Back, M. H., Can. J. Chem., 49, 2199 (1971).

8) Cullis, G. F., Franklin, N. H., Proc. Roy. Soc. A, 280, 139 (1964).

9) Minkoff, G. J., Newitt, D. M., Rutledge, P., J. Appl. Chem., 7, 406 (1957).

10) Silcocks, C. G., Proc. Roy. Soc. A, 242, 411 (1957).

11) Gullis, G. F., Minkoff, G. J., Nettleton, M. A., Trans. Faraday Soc., 58, 117 (1962).

12) Rice, F. O., Walters, W. D., J. Am. Chem. Soc., 63, 1701 (1941).

13) Sakai, T., Nohara, D., Kungi, T., “ACS Symp. Ser., Industrial and Laboratory Pyrolyses”, 32, 152 (1976). 
野原大 輔*, 酒井朝 也**.

ビアリルをアリルラジカル生成源として用い, アリルラジカ ルとアセチレンの反応を行った。反応装置は常圧流通式のもの であり，ビアリルおよびアセチレンを $\mathrm{N}_{2}$ 中とれぞれ約 0.16 および $4 \mathrm{~mol} \%$ の濃度とし, 反応温度は $580 \sim 740^{\circ} \mathrm{C}$, 滞留時 間は $0.09 \sim 0.3 \mathrm{sec}$ であった。

ブランクとしてビアリル蒸気を添加しないアセチレン $\mathrm{N}_{2}$ 混 合ガスの実験も行った。この反応の主生成物はビニルアセチレ ンおよびベンゼンであった。これらの生成曲線を，ビアリル蒸 気を添加した場合のものと並べて Fig. 1 に示した。

アリルソースとしてのビアリルの分解反応は一次反応として 整理でき，その結果を Fig. 2 に示した。

本反応の実験結果の一部を Table 1 に, 生成物分布を Fig. 3 に示した。アリルラジカル付加生成物として検出される $\mathrm{C}_{5}$ 化合物の中で，シクロペンタジェンが $90 \%$ 以上といら高い選 択性をもって生成した。一方，対応して生成されると考えられ る非環状の $\mathrm{C}_{5}$ 化合物， 1,4 -ペンタジェンは極く少量しか存在 しなかった。この結果は前に行ったビアリルとェチレンの反応 により，1-ペンテンがシクロペンテンとほぼ等モル生成した事

* 名古屋市立大学薬学部 (467 名古屋市瑞穂区田辺通 3-1)
実と大いに異なり，アリルラジカルのアセチレンへの付加にお いては環状化合物の生成速度が 非常に大きいことを示してい る。また，ビアリル蒸気の添加量を変化させ，他は同一条件に 保って行った反応の結果を Fig. 4 に示した。ビニルアセチレ ン，ベンゼン等アセチレン単味の反応生成物以外の生成物は明 らかにビアリル濃度に依存していることが示されている。

今回の反応に拈けるシクロペンタジェン生成速度の温度依存 性を Fig. 5 に示し $113 \mathrm{kJmol}^{-1}$ を得た。また，前回行った ビアリルとェチレンの反応に怙けるシクロペンテン拈よび 1ペンテンの生成速度の温度依存性を Fig. 6 に示した。これに より，51.3 および72.1 $\mathrm{kJmol}^{-1}$ を得た。ビアリルオギザレー ト $(\mathrm{DAO})$ をアリルラジカル生成源として用いた DAO と土 チレンの反応により，アリルラジカルとェチレンからシクロペ ンテンおよび 1-ペンテンが生成する 2 次速度定数の温度依存 性はそれぞれ 48.0 抢よび $69.6 \mathrm{kJmol}^{-1}$ と求まっている。 51.3 扎よび $72.1 \mathrm{kJmol}^{-1}$ との差はアリルラジカル濃度の温 度依存性分である。これを考慮して，アリルラジカルとアセチ レンの付加によるシクロペンタジェン生成の 2 次速度定数の温 度依存性を $110 \mathrm{kJmol}^{-1}$ と推算した。

\section{Keywords}

Allyl radical, Acetylene, Gycloaddition, Gyclopentadiene, Kinetics 